\title{
STRUCTURES AND ABSOLUTE CONFIGURATIONS OF CARPETIMYCINS A AND B
}

\author{
Masahito Nakayama, Shigeru Kimura, Sohei Tanabe, Toshimi Mizoguchi, \\ IsAmu Watanabe and TOSHIHITO Mori
}

Tokyo Research Laboratories, Kowa Co., Ltd., Higashimurayama, Tokyo 189, Japan

Kazumoto Miyahara and Toshio Kawasaki

Faculty of Pharmaceutical Sciences, Kyushu University 62, Fukuoka 812, Japan

(Received for publication April 24, 1981)

\begin{abstract}
The structures and stereochemistries of carpetimycins A (1) and B (2) have been determined as shown below.
\end{abstract}

Carpetimycins A and B, two new $\beta$-lactam antibiotics related to thienamycin ${ }^{1)}$, epithienamycins ${ }^{2}$, olivanic acids ${ }^{3 \sim 5)}$ and PS- ${ }^{6)}$, were found in the culture filtrate of Streptomyces sp. KC-6643. These antibiotics have strong activity against Gram-positive and Gram-negative bacteria including $\beta$-lactamase producing strains. Although the carbapenem antibiotics have been reported to be unstable substances, carpetimycins A and B are more stable than olivanic acids.

In a previous paper $^{7)}$, we presented the isolation, characterization, biological properties and structures of these antibiotics.

In this paper, we describe the structure elucidation including stereochemistry of carpetimycins $A$ and $\mathrm{B}$ on the basis of chemical studies and X-ray analysis.

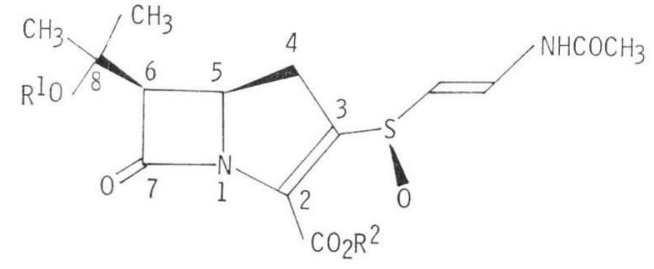

(1) $\mathrm{R}^{1}=\mathrm{H}$,

(2) $\mathrm{R}^{1}=\mathrm{SO}_{3} \mathrm{H}, \quad \mathrm{R}^{2}=\mathrm{H}$

(3) $\mathrm{R}^{1}=\mathrm{H}, \quad \mathrm{R}^{2}=\mathrm{CH}_{3}$

(4) $\mathrm{R}^{1}=\mathrm{H}, \quad \mathrm{R}^{2}=\mathrm{CH}_{2} \mathrm{C}_{6} \mathrm{H}_{4}\left(\mathrm{NO}_{2}\right)-p$

(5) $\mathrm{R}^{1}=\mathrm{SO}_{3} \mathrm{H}, \quad \mathrm{R}^{2}=\mathrm{CH}_{2} \mathrm{C}_{6} \mathrm{H}_{4}\left(\mathrm{NO}_{2}\right)-p$

(6) $\mathrm{R}^{1}=\mathrm{H}, \quad \mathrm{R}^{2}=\mathrm{CH}_{2} \mathrm{C}_{6} \mathrm{H}_{4} \mathrm{Br}-p$

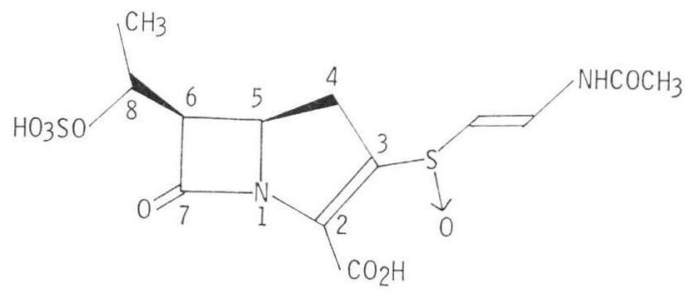

MM 4550 (MC696-SY2-A)

\section{Structures and Absolute Configurations}

Carpetimycins A (1) and B (2) were isolated as freeze-dried sodium salts. The UV spectrum of carpetimycin A showed two maxima at $\lambda_{\max }^{\mathrm{H}_{2} \mathrm{O}} 240 \mathrm{~nm}\left(\mathrm{E}_{1 \mathrm{~cm}}^{1 \%} 369\right)$ and $288 \mathrm{~nm}\left(\mathrm{E}_{1 \mathrm{em}}^{1 \%} 300\right)$. The IR band

Presented at the 220th Scientific Meeting of Japan Antibiotics Research Association, Tokyo, 12 Sept. 1980 and at the 20th Intersci. Conf. Antimicr. Agents \& Chemoth., New Orleans, La., Abstract No. 165, $22 \sim 24$ Sept. 1980 
Table 1. Chemical shifts and coupling constants of ${ }^{1} \mathrm{H}$ NMR spectra of carpetimycins $\mathrm{A}(\mathbf{1})$ and $\mathrm{B}(2)$ in $\mathrm{D}_{2} \mathrm{O}$.

\begin{tabular}{|c|c|c|c|c|}
\hline \multirow{2}{*}{ Proton } & \multicolumn{2}{|c|}{1} & \multicolumn{2}{|c|}{2} \\
\hline & $\mathrm{ppm}$ & $J(\mathrm{~Hz})$ & $\mathrm{ppm}$ & $J(\mathrm{~Hz})$ \\
\hline $8-\mathrm{CH}_{3}$ & 1.83 & & 2.15 & \\
\hline $8-\mathrm{CH}_{3}$ & 1.91 & & 2.23 & \\
\hline $6-\mathrm{CH}$ & 4.32 & 5.5 & 4.50 & 5.5 \\
\hline $5-\mathrm{CH}$ & 4.98 & $5.5,8,11$ & 5.04 & $5.5,8,11$ \\
\hline $4-\mathrm{CH}_{2}$ & 3.54 & 11,17 & 3.62 & 11,18 \\
\hline $4-\mathrm{CH}_{2}$ & 4.43 & 8,17 & 4.42 & 8,18 \\
\hline $\mathrm{N}-\mathrm{COCH}_{3}$ & 2.65 & & 2.65 & \\
\hline $\mathrm{N}-\mathrm{CH}=$ & 6.92 & 14 & 6.95 & 14 \\
\hline $\mathrm{S}-\mathrm{CH}=$ & 8.10 & 14 & 8.13 & 14 \\
\hline
\end{tabular}

$\mathrm{Me}_{4} \mathrm{Si}$ as external standard.

at $1770 \mathrm{~cm}^{-1}$ in the spectrum of $\mathbf{1}$ was attributed to a $\beta$-lactam carbonyl group. The CD spectrum of 1 showed at $[\theta]_{\mathrm{nm}}^{\mathrm{H}_{2} \mathrm{O}} 210(-1.90 \times$ $\left.10^{4}\right), 235\left(+7.22 \times 10^{4}\right), 260\left(-6.27 \times 10^{4}\right)$ and $300\left(-3.17 \times 10^{4}\right)$. It was suggested from the above data that $\mathbf{1}$ had the same chromophore as MM 45503) (MC696-SY2-A) ${ }^{8}$ ) having a sulfoxide function. The molecular formula of $\mathbf{1}$ was established as $\mathrm{C}_{14} \mathrm{H}_{18} \mathrm{~N}_{2} \mathrm{O}_{6} \mathrm{~S}$ from the FD mass spectrum of the methyl ester [(3), $\mathrm{MH}^{+}$357], the elemenal analysis and the ${ }^{13} \mathrm{C}$ NMR spectrum. Instead of a doublet methyl signal in the ${ }^{1} \mathrm{H}$ NMR spectrum of MM 4550, two singlet methyl signals were observed in that of 1 (Table 1). The orientation of H-5 and H-6 in $\mathbf{1}$ was determined to be cis virtue of the observed coupling constants $\left(J_{5,6}=5.5 \mathrm{~Hz}\right)$. The ${ }^{13} \mathrm{C}$ NMR spec-
Table 2. ${ }^{13} \mathrm{C}$ Chemical shifts (ppm) of carpetimycins $\mathbf{A}(\mathbf{1})$ and $\mathbf{B}(\mathbf{2})$ in $\mathrm{D}_{2} \mathrm{O}$.

\begin{tabular}{l|c|c}
\hline \multicolumn{1}{c|}{ Carbon } & $\mathbf{1}$ & $\mathbf{2}$ \\
\hline $\mathrm{C}=\mathrm{O}$ & $179.6(\mathrm{~s})$ & $178.0(\mathrm{~s})$ \\
$\mathrm{C}=\mathrm{O}$ & $173.6(\mathrm{~s})$ & $173.7(\mathrm{~s})$ \\
$\mathrm{C}=\mathrm{O}$ & $166.5(\mathrm{~s})$ & $166.3(\mathrm{~s})$ \\
$2-\mathrm{C}=$ & $141.5(\mathrm{~s})$ & $140.5(\mathrm{~s})$ \\
$3-\mathrm{C}=$ & $138.0(\mathrm{~s})$ & $139.6(\mathrm{~s})$ \\
$\mathrm{NHCH}=$ & $134.9(\mathrm{~d})$ & $134.9(\mathrm{~d})$ \\
$\mathrm{S}-\mathrm{CH}=$ & $112.7(\mathrm{~d})$ & $113.0(\mathrm{~d})$ \\
$\mathrm{C}-\mathrm{O}$ & $71.8(\mathrm{~s})$ & $85.0(\mathrm{~s})$ \\
$5-\mathrm{CH}$ & $63.8(\mathrm{~d})$ & $64.0(\mathrm{~d})$ \\
$6-\mathrm{CH}$ & $55.1(\mathrm{~d})$ & $55.0(\mathrm{~d})$ \\
$4-\mathrm{CH}$ & $29.4(\mathrm{t})$ & $29.7(\mathrm{t})$ \\
$\mathrm{CH}_{3}-\mathrm{CO}$ & $29.6(\mathrm{q})$ & $26.2(\mathrm{q})$ \\
$\mathrm{CH}_{3}>\mathrm{C}-$ & $28.0(\mathrm{q})$ & $25.1(\mathrm{q})$ \\
$\mathrm{CH}_{3}>$ & $23.5(\mathrm{q})$ & $23.6(\mathrm{q})$ \\
\hline
\end{tabular}

$\mathrm{Me}_{4} \mathrm{Si}$ as external standard trum (Table 2) of $\mathbf{1}$ revealed fourteen carbons, and indicated the presence of a tetra substituted carboncarbon double bond (C-2-C-3) and a tetra substituted carbon (C-8, $\delta$ 71.8). The C-8 carbon in MM 4550 was observed as a tri substituted carbon. Esterification of $\mathbf{1}$ with $p$-nitrobenzyl bromide in dimethylformamide afforded the $p$-nitrobenzyl ester (4). The ${ }^{1} \mathrm{H}$ NMR spectrum of 4 in $\mathrm{DMF}-d_{7}$ showed an exchangeable hydroxy proton $(\delta 4.97)$. The $R$ configuration of C-5 was probable as in all other known naturally occurring $\beta$-lactam antibiotics ${ }^{5)}$ and confirmed by X-ray crystallographic analysis as described below.

Thus, the structure of $\mathbf{1}$ was proposed as $(5 R, 6 R)-3-[(E)-2$-acetamidoethenylsulfinyl]-6-(2-hydroxy2-propyl)-7-oxo-1-azabicyclo[3,2,0]hept-2-ene-2-carboxylic acid.

The structure of carpetimycin B (2) was suggested to be similar to 1 from its spectral data. The UV and CD spectra of 2 showed $\lambda_{\max }^{\mathrm{H}_{2} \mathrm{O}} 240 \mathrm{~nm}\left(\mathrm{E}_{1 \mathrm{~cm}}^{1 \%} 357\right)$ and $285 \mathrm{~nm}\left(\mathrm{E}_{1 \mathrm{~cm}}^{1 \%} 305\right)$, and $[\theta]_{\mathrm{nm}}^{\mathrm{H}_{2} \mathrm{O}} 210(-2.35$ 
$\left.\times 10^{4}\right), 235\left(+7.14 \times 10^{4}\right), 261\left(-5.85 \times 10^{4}\right)$ and $300\left(-3.78 \times 10^{4}\right)$, respectively. The ${ }^{1} \mathrm{H}$ NMR and ${ }^{13} \mathrm{C}$ NMR signals of 2 were listed in Tables 1 and 2. The ${ }^{13} \mathrm{C}$ NMR data and the elemental analysis for 2 agreed with the molecular formula $\mathrm{C}_{14} \mathrm{H}_{18} \mathrm{~N}_{2} \mathrm{O}_{9} \mathrm{~S}_{2}$. The IR spectrum of 2 indicated the presence of sulfate $\left(1270 \sim 1220\right.$ and $\left.1050 \mathrm{~cm}^{-1}, \mathrm{KBr}\right)$, which was not observed in that of $\mathbf{1}$. The exchangeable hydroxy proton was not observed in the ${ }^{1} \mathrm{H}$ NMR spectrum of $p$-nitrobenzyl ester (5) of 2 in DMF- $d_{7}$. In the ${ }^{13} \mathrm{C}$ NMR spectra (Table 2), the most significant difference between $\mathbf{1}$ and $\mathbf{2}$ was the marked deshielding of the C-8 carbon resonance from $85.0 \mathrm{ppm}$ in the latter to $71.8 \mathrm{ppm}$ in the former. It was apparent from the above evidence that the hydroxy function of $\mathbf{1}$ was absent and replaced by a sulfate moiety. This was confirmed by the fact that the mild acid hydrolysis of $\mathbf{2}$ afforded $\mathbf{1}$ and sulfate ion.

Thus, the structure of $\mathbf{2}$ was proposed as $(5 R, 6 R)-3-[(E)$-2-acetamidoethenylsulfinyl]-6-(2-hydroxysulfonyloxy-2-propyl)-7-oxo-1-azabicyclo[3,2,0]hept-2-ene-2-carboxylic acid. Lately, the similar structures to $\mathbf{1}$ and $\mathbf{2}$ have been reported by other workers as C-19393 $\mathrm{H}_{2}$ and $\mathrm{S}_{2}{ }^{9)}$.

The complete structures of $\mathbf{1}$ and $\mathbf{2}$ were determined from the X-ray crystallographic analysis of $p$-bromobenzyl ester of $\mathbf{1}$.

Carpetimycin A p-bromobenzyl ester (6) was prepared and crystallized from acetone - $n$-hexane to afford colorless needles. Crystal data: $\mathrm{C}_{21} \mathrm{H}_{23} \mathrm{~N}_{2} \mathrm{O}_{6} \mathrm{SBr}(\mathrm{MW}=511.39)$, orthorhombic, space group $\mathrm{P}_{2_{121} 2_{1}}, a=16.901$ (4), $b=13.359$ (3), $c=10.001$ (2) $\AA, V=2258.0 \AA^{3}, \mathrm{D}_{\text {calcd. }}=1.504 \mathrm{gcm}^{-3}, \mathrm{D}_{\text {obsd. }}=1.52$ $\mathrm{gcm}^{-3}$ (in $\mathrm{CCl}_{4}$ - $n$-hexane solution), $Z=4$.

Cell constants and intensity data were determined on a SYNTEX $P_{\overline{1}}$ computer-controlled fourcircle diffractometer with graphite monochromated Mo $\mathrm{K} \alpha$ radiation $(\lambda=0.71069 \AA)$ using a crystal with approximate dimensions of $0.15 \times 0.2 \times 0.45 \mathrm{~mm}$. A total of 2296 unique intensities were collected by $2 \theta-\theta$ scanning technique with $2 \theta$ less than $50.0^{\circ}$, among which 1420 with $I>2 \sigma(I)$ were regarded to be observed. Two reference reflections were monitored every 58 reflections and their intensities decreased by $22 \%$ at the end of data collection. After usual decay correction, the intensities were further corrected for Lorenz and Polarization factors, but not for absorption and extinction.

Fig. 1. Bond angles and bond distances in carpetimycin A p-bromobenzyl ester (6).

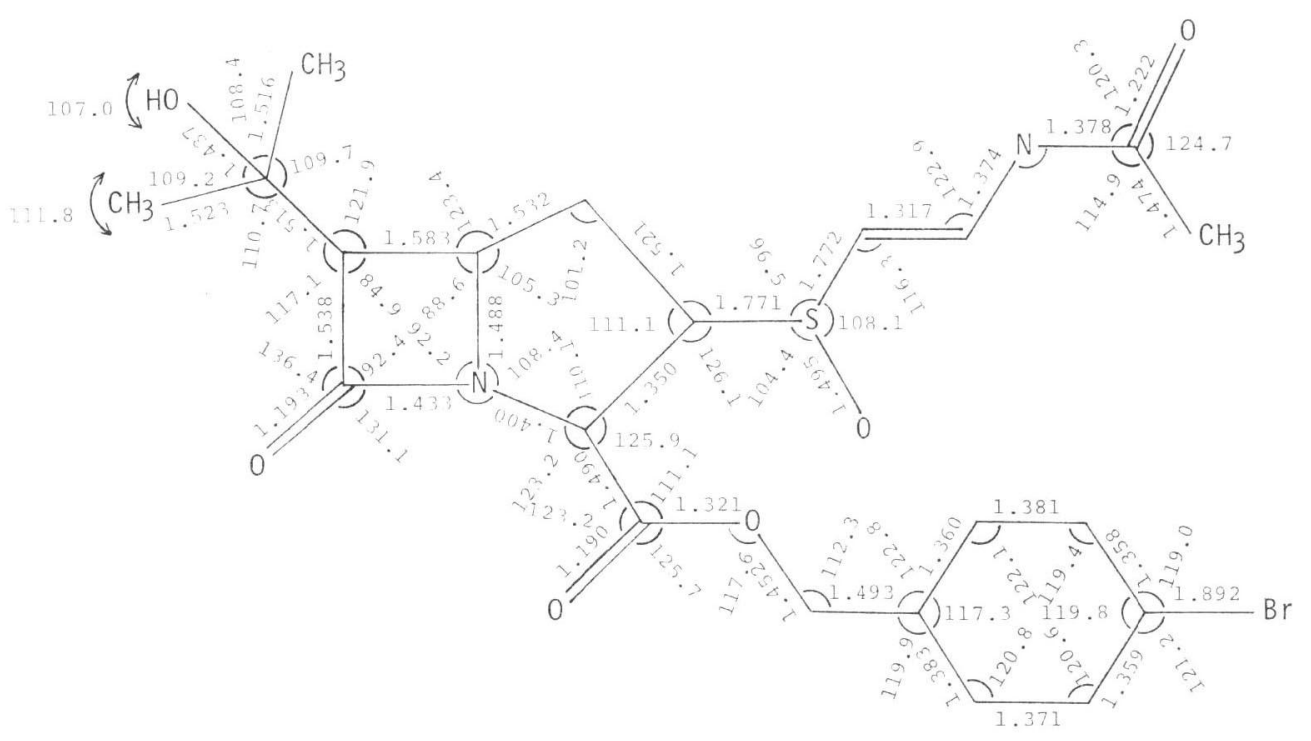


The structure was solved by heavy-atom method and block-diagonal least-squares refinement with anisotropic non-hydrogen and isotropic hydrogen atoms other than those of hydroxy and amide groups for the observed reflections converged the R-factor to the final value of 0.047. The atomic scattering factors were taken from International Tables for X-ray Crystallography $^{10)}$. The structure of antipode of 6 was refined to give the $\mathrm{R}$-factor value of 0.067 .

The bond lengths and the bond angles for non-hydrogen atoms are shown in Fig. 1. The stereoscopic view ${ }^{11)}$ of 6 is shown in Fig. 2.

Thus, the structures and stereochemistries of carpetimycins A and B have been determined to be $(5 R, 6 R)$-3-[(E)-2-acetamidoethenyl-( $R$ )-sulfinyl]-6-(2-hydroxy-2-propyl) -7-oxo-1-azabicyclo [3,2,0] hept2-ene-2-carboxylic acid and $(5 R, 6 R)-3-[(E)$-2-acetamidoethenyl-( $R$ )-sulfinyl]-6-(2-hydroxysulfonyloxy-2propyl)-7-oxo-1-azabicyclo[3,2,0]hept-2-ene-2-carboxylic acid, respectively. It is the first establishment among natural carbapenem antibiotics that the configuration of sulfoxide has been determined.

The sum of three nitrogen bond angles $\left(\Sigma_{\mathrm{N}}\right)$ and the distance $(D)$ of the nitrogen from the plane of the attached three carbon atoms were calculated from the available X-ray data of 6 . The derivative of 1 with $\Sigma_{\mathrm{N}}=326.3^{\circ}$ and $D=0.51 \AA$ is the most folded fused $\beta$-lactam ring system, similar to the thienamycin derivative ${ }^{1)}$ with $\Sigma_{\mathrm{N}}=325.9^{\circ}$ and $D=0.49 \AA$. It seems that the high chemical and biological reactivities of carpetimycins are partly based on its geometry.

\section{Experimental}

IR spectra were obtained with a JASCO-403G spectrophotometer. UV spectra were recorded with a Hitachi 200-20 spectrophotometer. ORD and CD spectra were obtained with a JASCO J-20 and a JASCO J-500C with DP-500 instruments, respectively. Optical rotations were measured on a JASCO DIP-4 digital polarimeter. ${ }^{1} \mathrm{H}$ NMR and ${ }^{13} \mathrm{C}$ NMR spectra were measured at $100 \mathrm{MHz}$ on a JEOL FX-100 spectrometer with $\mathrm{Me}_{4} \mathrm{Si}$ as internal standard. FD mass spectra were obtained with a JEOL JMS 01 SG-2 spectrometer.

All the calculations of X-ray analysis were performed on a FACOM M-190 computer at the Computer Center of Kyushu University using the UNICS II programs ${ }^{12}$.

Carpetimycin A Methyl Ester (3)

To a solution of $\mathbf{1}(5 \mathrm{mg})$ in dry dimethylformamide $(1 \mathrm{ml})$, methyl iodide $(0.06 \mathrm{ml})$ was added. The solution was stirred for 3 hours at room temperature. The reaction mixture was evaporated to dryness under reduced pressure. The residue was chromatographed on two prewashed silica gel $\mathrm{HF}_{254}$ plates (E. Merck, $20 \times 20 \times 0.05 \mathrm{~cm}$ ) in methylene chloride-methanol (9: 1). The zone at Rf 0.34 corresponding to 3 was collected and eluted with the same solvent to afford pure 3 ( $3.6 \mathrm{mg})$ : $\operatorname{mp~} 143 \sim 144^{\circ} \mathrm{C} ;[\alpha]_{\mathrm{D}}^{24.5}-96.0^{\circ}\left(c 1, \mathrm{CH}_{2} \mathrm{Cl}_{2}\right)$; IR $(\mathrm{KBr}) 1780,1715,1620,1500,1435,1370,1330,1260$ $\mathrm{cm}^{-1}$; UV (MeOH) $244\left(\varepsilon\right.$ 17,700), $299(11,000) \mathrm{nm} ;{ }^{1} \mathrm{H}$ NMR $\left(\mathrm{CDCl}_{3}\right) \delta 1.29,1.49(\operatorname{each} 3 \mathrm{H}, \mathrm{s}, \mathrm{C}(\mathrm{CH})-$ $\left.\mathrm{CH}_{3}\right), 2.11\left(3 \mathrm{H}, \mathrm{s}, \mathrm{COCH}_{3}\right), 2.98(1 \mathrm{H}, \mathrm{dd}, J=15.0,23.0 \mathrm{~Hz}, \mathrm{H}-4), 3.55(1 \mathrm{H}, \mathrm{d}, J=5.7 \mathrm{~Hz}, \mathrm{H}-6), 3.87$ $\left(3 \mathrm{H}, \mathrm{s}, \mathrm{OCH}_{3}\right), 4.25(2 \mathrm{H}, \mathrm{m}, \mathrm{H}-4, \mathrm{H}-5), 6.27(1 \mathrm{H}, \mathrm{d}, J=13.6 \mathrm{~Hz}, \mathrm{SO}-C H=\mathrm{CH}), 7.56(1 \mathrm{H}, \mathrm{dd}, J=10.8$, $13.6 \mathrm{~Hz}, \mathrm{CH}=\mathrm{CH}-\mathrm{NH}), 8.86(1 \mathrm{H}, \mathrm{br}-\mathrm{d}, J=10.8 \mathrm{~Hz}, \mathrm{NH}) ;{ }^{13} \mathrm{C} \mathrm{NMR}\left(\mathrm{CDCl}_{3}\right) \delta 23.3,28.1\left(\mathrm{q}, \mathrm{C}\left(\mathrm{CH}_{3}\right)-\right.$ $\mathrm{CH}_{3}$ ), 29.7 (q, $\mathrm{COCH}_{3}$ ), 29.7 (t, C-4), 52.9 (q, $\mathrm{OCH}_{3}$ ), 53.9 (d, C-6), 63.7 (d, C-5), 70.6 (s, C-8), 111.2 $(\mathrm{d}, \mathrm{SO}-\mathrm{CH}=\mathrm{CH}), 131.7(\mathrm{~s}, \mathrm{C}-3), 134.0(\mathrm{~d}, \mathrm{CH}=\mathrm{CH}-\mathrm{NH}), 148.2(\mathrm{~s}, \mathrm{C}-2), 160.2,169.1,175.7(\mathrm{~s}, \mathrm{C}=\mathrm{O})$; FD mass $m / z 357\left(\mathrm{MH}^{+}\right), 340,308$. 
Anal. Calcd. for $\mathrm{C}_{15} \mathrm{H}_{20} \mathrm{~N}_{2} \mathrm{O}_{6} \mathrm{~S}$ : C, $50.55 ; \mathrm{H}, 5.66 ; \mathrm{N}, 7.86 ; \mathrm{S}, 9.00$. Found: $\quad$ C, $50.61 ; \mathrm{H}, 5.69 ; \mathrm{N}, 7.82 ; \mathrm{S}, 8.92$.

$\mathrm{CD}(c 0.1, \mathrm{MeOH})[\theta] 215\left(-3.476 \times 10^{4}\right), 244\left(+4.757 \times 10^{4}\right), 265\left(-1.427 \times 10^{4}\right), 298\left(-2.671 \times 10^{4}\right)$ $\mathrm{nm}$; ORD $(c 0.1, \mathrm{MeOH})[\phi] 231\left(-3.549 \times 10^{2}\right), 255\left(+5.122 \times 10^{2}\right), 280\left(+2.415 \times 10^{2}\right), 328(-1.208$ $\left.\times 10^{2}\right) \mathrm{nm}$.

Carpetimycin A p-Nitrobenzyl Ester (4)

A solution of $\mathbf{1}(5 \mathrm{mg})$ and p-nitrobenzyl bromide $(7 \mathrm{mg})$ in dry dimethylformamide $(1 \mathrm{ml})$ was stirred at room temperature for 3 hours. The reaction mixture was evaporated to dryness under reduced pressure. Preparative chromatography of the evaporation residue on two prewashed silica gel $\mathrm{HF}_{254}$ plates in methylene chloride - methanol (9: 1) gave 4 (3 mg, $\left.\mathrm{Rf} 0.38\right)$ : IR ( $\left.\mathrm{KBr}\right) 1785,1710,1620$, $1520,1365,1345,1320,1250 \mathrm{~cm}^{-1}$; UV $(\mathrm{MeOH}) 250(\varepsilon 17,900), 305(9,400) \mathrm{nm} ;{ }^{1} \mathrm{H}$ NMR $\left(\mathrm{DMF}-d_{7}\right)$ o 1.28, 1.45 (each $\left.3 \mathrm{H}, \mathrm{s}, \mathrm{C}\left(\mathrm{CH}_{3}\right) \mathrm{CH}_{3}\right), 2.06\left(3 \mathrm{H}, \mathrm{s}, \mathrm{COCH}_{3}\right), 4.97(1 \mathrm{H}, \mathrm{s}, \mathrm{OH}), 5.40,5.59(\mathrm{each} 1 \mathrm{H}, \mathrm{d}$, $J=13.6 \mathrm{~Hz}, \mathrm{CH} \mathrm{Ar}_{2}, 6.34(1 \mathrm{H}, \mathrm{d}, J=14.1 \mathrm{~Hz}, \mathrm{SO}-\mathrm{CH}=\mathrm{CH}), 7.48(1 \mathrm{H}, \mathrm{dd}, J=10.5,14.1 \mathrm{~Hz}, \mathrm{CH}=$ $\mathrm{CH}-\mathrm{NH}$ ), 7.48, 8.29 (each 2H, d, $J=8.8 \mathrm{~Hz}, \mathrm{Ar} H$ ), $10.58(1 \mathrm{H}$, br-d, $J=10.5 \mathrm{~Hz}, \mathrm{NH}$ ).

Carpetimycin B p-Nitrobenzyl Ester (5)

Under the same conditions as described above, 5 [3.5 mg, $\mathrm{Rf} 0.32, \mathrm{CH}_{2} \mathrm{Cl}_{2}-\mathrm{MeOH}$ (4: 1)] was prepared by treatment of $2(5 \mathrm{mg})$ with $p$-nitrobenzyl bromide $(5 \mathrm{mg})$ : IR $(\mathrm{KBr}) 1790,1720,1620$, 1510, 1420, 1370, 1350, 1320, $1280 \sim 1210$ (br) cm $\mathrm{cm}^{-1}$; UV (MeOH) $251(\varepsilon 19,200), 300(11,400) \mathrm{nm}$; ${ }^{1} \mathrm{H}$ NMR $\left(\mathrm{DMF}-d_{7}\right) \delta 1.58,1.60\left(\right.$ each $\left.3 \mathrm{H}, \mathrm{s}, \mathrm{C}\left(\mathrm{CH}_{3}\right) \mathrm{CH}_{3}\right), 2.06\left(3 \mathrm{H}, \mathrm{s}, \mathrm{COCH}_{3}\right), 5.40,5.58($ each $\left.1 \mathrm{H}, \mathrm{d}, J=13.5 \mathrm{~Hz}, \mathrm{CH} \mathrm{H}_{2} \mathrm{Ar}\right), 6.37(1 \mathrm{H}, \mathrm{d}, J=13.6 \mathrm{~Hz}, \mathrm{SO}-\mathrm{CH}=\mathrm{CH}), 7.48(1 \mathrm{H}, \mathrm{dd}, J=10.6,13.6 \mathrm{~Hz}$, $\mathrm{CH}=\mathrm{CH}-\mathrm{NH}), 7.84,8.28($ each $2 \mathrm{H}, \mathrm{d}, J=8.4 \mathrm{~Hz}, \mathrm{Ar} H), 10.61(1 \mathrm{H}, \mathrm{br}-\mathrm{d}, J=10.6 \mathrm{~Hz}, \mathrm{NH})$.

\section{Carpetimycin A p-Bromobenzyl Ester (6)}

Under the same conditions as prepared 4, 6(10 mg, Rf 0.62) was obtained by treatment of 1 $(20 \mathrm{mg})$ with $p$-bromobenzyl bromide $(40 \mathrm{mg})$. The resulting solid was crystallized from acetone $-n$ hexane to give 6 which was recrystallized from the same solvent system to obtain sturdy and wellformed needles for X-ray analysis: $\operatorname{mp~} 149 \sim 149.5^{\circ} \mathrm{C}$; IR $(\mathrm{KBr}) 1785,1710,1620 \mathrm{~cm}^{-1}$; UV (MeOH) 228 ( $\varepsilon 19,500), 245(16,400), 303(9,800) \mathrm{nm}$.

Anal. Calcd. for $\mathrm{C}_{21} \mathrm{H}_{23} \mathrm{~N}_{2} \mathrm{O}_{6} \mathrm{SBr}$ : C, $49.32 ; \mathrm{H}, 4.53 ; \mathrm{N}, 5.48 ; \mathrm{S}, 6.27$.

Found:

C, 49.39; H, 4.55; N, 5.44; S, 6.21 .

Hydrolysis of Carpetimycin B (2)

A solution of $2(80 \mathrm{mg})$ in $2 \mathrm{ml}$ of $0.01 \mathrm{M}$ acetate buffer $\mathrm{pH} 6.0$ was heated at $60^{\circ} \mathrm{C}$ for 2 hours. The hydrolysate was purified by semipreparative HPLC using a Bondapak $\mathrm{C}_{18}$ /Porasil B column (Waters Assoc., $0.8 \times 120 \mathrm{~cm}$ ) with $2 \% \mathrm{MeOH}$ in $0.05 \mathrm{M}$ phosphate buffer $\mathrm{pH} 6.8$. The active eluate was desalted with Diaion HP-20 resin (Mitsubishi Kasei Kogyo). The desalted eluate was freeze-dried to give 1 ( $5 \mathrm{mg})$, which was identical with the authentic product obtained from the fermentation in physico-chemical and biological properties.

\section{Acknowledgement}

The authors are grateful to Dr. H. UMEZAWA and Dr. K. MAEDA, Institute of Microbial Chemistry, for their advices and encouragement in the performance of this work. Thanks are also due to Prof. I. UEDA and Prof. S. Kono, College of General Education, and Prof. T. Komori, Faculty of Pharmaceutical Science, Kyushu University, for providing their programs of X-ray analysis. Thanks are also due to Dr. H. TANI and Dr. T. OdA for their helpful advices and encouragement.

\section{References}

1) Alberg-Schönberg, G.; B. H. Arison, O. D. Hensens, J. Hirshfield, K. Hoogsteen, E. A. Kaczka, R. E. Rhodes, J. S. Kahan, F. M. Kahan, R. W. Ratchiffe, E. Walton, L. J. Ruswinkle, R. B. Morin \& B. G. Christensen: Structure and absolute configuration of thienamycin. J. Am. Chem. Soc. 100: $6491 \sim 6499,1978$ 
2) Cassidy, P. J.; E. O. Stapley, R. Goegelman, T. W. Miller, B. Arison, G. Albers-SchönberG, S. B. ZIMMERMAN \& J. BIRNBAUM: Epithienamycins. Isolation and identification of epithienamycins. Presented at the 17th Intersci. Conf. Antimicr. Agents \& Chemoth., Abstract No. 80, New York, N. Y., $12 \sim 14$ Oct. 1977

3) Brown, A. G.; D. F. Corbett, A. J. Eglington \& T. T. Howarth: Structure of olivanic acid derivatives, MM 4550 and MM 13902, two new, fused $\beta$-lactams isolated from Streptomyces olivaceus. J. Chem. Soc., Chem. Comm. 1977: 523 525, 1977

4) Corbett, D. F.; J. Eglingston \& T. T. Howarth: Structure elucidation of MM 17880, a new fused $\beta$-lactam antibiotic isolated from Streptomyces olivaceus; a mild $\beta$-lactam degradation reaction. J. Chem. Soc., Chem. Comm. 1977: 953 954, 1977

5) Brown, A. G.; D. F. Corbett, A. J. Eglington \& T. T. Howarth: Structures of olivanic acid derivatives, MM 22380, MM 22381, MM 22382 and MM 22383. J. Antibiotics 32: 961 963, 1979

6) Yamamoto, K.; T. Yoshioka, Y. Kato, N. Shibamoto, K. Okamura, Y. Shimauchi \& T. Ishikura: Structure and stereochemistry of antibiotic PS-5. J. Antibiotics 33: 796 803, 1980

7) Nakayama, M.; A. Ifasaki, S. Kimura, T. Mizoguchi, S. Tanabe, A. Murakami, M. Okuchi, H. Itoh, Y. SAINo, F. Kobayashi \& T. Mori: Carpetimycins A and B, new $\beta$-lactam antibiotics. J. Antibiotics 33: $1388 \sim 1390,1980$

8) Maeda, K.; S. Takahashi, M. Sezaki, I. Innuma, H. Naganawa, S. Kondo, M. Ohno \& H. Umezawa: Isolation and structure of a $\beta$-lactamase inhibitor from Streptomyces. J. Antibiotics 30: 770 772, 1977

9) Harada, S.; S. Shinagawa, Y. Nozaki, M. Asai \& T. Kishi: C-19393 $\mathrm{S}_{2}$ and $\mathrm{H}_{2}$, new carbapenem antibiotics. II. Isolation and structures. J. Antibiotics 33: 1425 1431, 1980

10) “International Tables for X-ray Crystallography." vol. III, p. 201, Kynoch Press, Birmingham, 1962

11) Johnson, C. K.; ORTEP, Oak Ridge National Laboratory Report ORNL-3794, 1965

12) Sakurai, T.; H. Iwasaki, Y. Watanabe, K. Kobayashi, Y. Bando \& Y. Nakamichi: On the universal crystallographic computation program system. 4. UNICS II system. Rikagaku Kenkyusho Hookoku 50: 75 91, 1974 (in Japanese). 